\title{
STRENGTHENING OF THE FOUNDATIONS OF RENOVATED BUILDINGS WITH INJECTION PILES
}

\author{
Anatoly I. Polishchuk ${ }^{1}$, Nadezhda S. Nikitina ${ }^{2}$, Arkady A. Petukhov', \\ Ivan V. Semyonov ${ }^{1}$ \\ ${ }^{1}$ Kuban State Agrarian University named after I. Trubilin, Krasnodar, RUSSIA \\ ${ }^{2}$ National Research Moscow State University of Civil Engineering, Moscow, RUSSIA
}

\begin{abstract}
The paper describes the technique of strengthening shallow foundations of reconstructed buildings using injection piles. First, the constructive solution of the existing foundations, the structural scheme of the building, as well as the loads transferred to the building structures before and after its reconstruction are established. At the same time, an assessment of the soil conditions of the construction site of the reconstructed building is carried out; a bearing soil layer is revealed for deepening the lower ends of injection piles. Based on the data obtained, the loading of the base of the foundations of the reconstructed building is assessed and the need for their reinforcement (or further operation without reinforcement) is established. In the case of strengthening the foundations of the building, the method of transferring the additional load to the injection piles is selected. Then their bearing capacity and design loads allowed on the piles are substantiated. The construction of foundations is carried out, taking into account their reinforcement with injection piles, which are hereinafter called combined. Verification calculations of the base of the combined foundations are performed for the first and second groups of limit states. In accordance with the regulatory documents, strength calculations of the main structural elements of foundations are carried out, which are necessary to ensure their full operation, taking into account the reinforcement. At the final stage, working documentation is developed to strengthen the foundations of the reconstructed building. The stages of the design of strengthening the foundations of reconstructed buildings using injection piles presented in the work allow to properly and consistently organize the work of specialists.
\end{abstract}

Keywords: reconstruction of buildings, soil conditions, shallow foundations, injection piles, calculation and design methods, foundation reinforcement, combined foundations.

\section{УСИЛЕНИЕ ФУНДАМЕНТОВ РЕКОНСТРУИРУЕМЫХ ЗДАНИЙ ИНЪЕКЦИОННЫМИ СВАЯМИ}

\author{
А.И. Полищук ${ }^{1}$, Н.С. Никитина ${ }^{2}$, А.А. Петухов ${ }^{1}$, И.В. Семёнов ${ }^{1}$ \\ ${ }^{1}$ Кубанский государственный аграрный университет им. И. Т. Трубилина, г. Краснодар, РОССИЯ \\ ${ }^{2}$ Национальный исследовательский Московский государственный строительный университет, \\ г. Москва, РОССИЯ
}

\begin{abstract}
Аннотация. Излагается методика усиления фундаментов мелкого заложения реконструируемых зданий с использованием инъекционных свай. Вначале устанавливается конструктивное решение существующих фундаментов, конструктивная схема здания, а также нагрузки, передаваемые на строительные конструкции до и после его реконструкции. Одновременно выполняется оценка грунтовых условий строительной площадки реконструируемого здания; выявляется несущий слой грунта для заглубления нижних концов инъекционных свай. На основе полученных данных производится оценка загружения основания фундаментов реконструируемого здания и устанавливается необходимость их усиления (или дальнейшей эксплуатация без усиления). В случае усиления фундаментов здания выбирается способ передачи дополнительной нагрузки на инъекционные сваи. Затем обосновывается их несущая способность и расчетные нагрузки, допускаемые на сваи. Производится конструирование фундаментов с учетом их усиления инъекционными сваями, которые в дальнейшем называются комбинированными. Выполняются поверочные расчеты основания комбинированных фундаментов по первой и второй группам предельных состояний. В соответствии с нормативными документами ведутся расчеты основных конструктивных элементов фундаментов на прочность, необходимых для обеспечения их полноценной работы с учетом усиления. На заключительном этапе разрабатывается рабочая документация по усилению фундаментов реконструируемого здания. Представленные в работе этапы проектирования усиления фундаментов реконструируемых зданий с использованием инъекционных свай позволяют правильно и последовательно организовать работу специалистов.
\end{abstract}

Ключевые слова: реконструкция зданий, фундаменты мелкого заложения, методика усиления фундаментов, инъекционные сваи, комбинированные фундаменты. 


\section{BASIC PROVISIONS}

During the reconstruction of buildings, the loads on the building structures often increase and the pressure along the bottom of the existing foundations increases. Such operating conditions of buildings can lead to a loss of the bearing capacity of the base, significant settlement of foundations, the development of cracks in walls and other building structures. Therefore, from time to time there is a need to strengthen the foundations and harden the soils of the base of the reconstructed buildings.

One of the ways to increase the bearing capacity of the foundation of shallow foundations is to change their operation scheme by transferring part of the load from the building to additionally arranged piles [15]. At the same time, in order to strengthen shallow foundations in clayey soils, injection cylindrical piles are increasingly being developed. They are arranged by pressing a metal injector into clay soil, followed by feeding a fine-grained mobile concrete mixture under pressure and pressing the wells [6-12].

\section{FOUNDATION REINFORCEMENT DESIGN METHODOLOGY}

The design technique for reinforcing shallow foundations using injection piles includes the following main stages:

1. Based on the results of the survey and the use of archival documentation, the constructive solution of the existing foundations, the structural scheme of the building, as well as the loads transferred to the building structures before and after the reconstruction of the building are established;

2. Assess the soil conditions of the construction site of the building to be reconstructed and identify the load-bearing soil layer for deepening the lower ends of injection piles used to strengthen the foundations;

3. Assess the loading of the shallow foundations of the building to be reconstructed and establish the need for their reinforcement (or further operation without reinforcement);
4. Choose a method for installing injection piles and transferring an additional load to them in case of strengthening the foundations of the building; 5. Substantiate the bearing capacity of the injection piles, as well as the design loads allowed on these piles.

6. Carry out the design of the foundations, taking into account their reinforcement with injection piles.

7. Perform verification calculations of the base of the reinforced foundations (combined) for the first and second groups of limiting states (for bearing capacity and deformations). The settlements of the foundations established in this case after their reinforcement and the transfer of an additional load should not exceed the permissible values;

8. Perform calculations of the main structural elements of foundations for strength (selection of reinforcement of reinforcement elements, designation of sections of thrust beams, calculation of foundations for punching, etc.), necessary to ensure their full operation, taking into account reinforcement; the solution to these issues is carried out in accordance with the regulatory documents (SP 16.13330.2017, SP 63.13330.2018, etc.).

9. Prepare working documentation for strengthening the foundations of the re-constructed building.

\section{MAIN DESIGN RESULTS AND THEIR APPLICATION}

\section{Constructive solution of existing foundations.}

The constructive solution of the foundations of the buildings under reconstruction is established, as a rule, according to the results of the examination of building structures and soils of the foundation. In this case, it is recommended to use design, executive and archival documentation for the building being reconstructed (conclusions, technical reports, inspection reports, etc.). Inspection of foundations is carried out more often from pits, which are laid in the most characteristic places of the building plan. Other methods, instruments and equipment are also 
used to inspect foundations, base soils. When examining foundations in prepared pits, their geometrical parameters are determined (depth, base width, thickness of the slab part, dimensions of the pocket foundation or wall part of the foundation, etc.) At the same time, during the examination, the strength characteristics of the foundation materials are determined and their defects are identified (the presence of concrete chips, brickwork, cracks, corrosion of reinforcement, violation of waterproofing, etc.). The strength of the foundation material is established by destructive or non-destructive methods.

Based on the results of a survey of foundations (including base soils), taking into account the identified defects and damages, an assessment of their technical condition is given in accordance with the recommendations of GOST 31937-2011. Details of the assessment methods can be found in the papers $[13,14,16]$.

At the design stage of foundation reinforcement, it is important to determine the loads transmitted to the foundations of the building before and after its reconstruction. Loads, as a rule, are installed at the level of the foundation cutoff, the external planning mark or the basement floor level (basement, technical floor). Constant loads (weight of bearing and enclosing structures, weight and pressure of soil, etc.), transferred to the foundations of the building before its reconstruction, are determined by the results of the survey of the building and the use of archival data (including measurements, identification of types building materials). Temporary loads are established depending on the purpose of the building (taking into account the weight of equipment and devices, people, furniture, etc.) and the area of its construction (snow, wind, seismic, etc.). The loads transferred to the foundations of the building after its reconstruction are usually established according to the data of the adopted design decisions, taking into account the technical condition of the design assignment.
Assessment of soil conditions. Assessment of the soil conditions of the construction site of a building being reconstructed is understood as a generalization of the results of studies of soil properties and composition of underground water performed at the stage of surveys (geotechnical, geotechnical, including archival, etc.), and identifying the possibility of their use as foundation base. Assessment of soil conditions of construction sites of reconstructed buildings is carried out based on the results of studying materials of geomorphology, lithological structure and engineering-geological sections, as well as physical and mechanical properties of soils and hydro-geological conditions of construction, which are given in reports (conclusions) for engineering and geological surveys. Assessment of soil conditions usually begins with an analysis of archived soil data from the site in question. The reliability and efficiency of the decisions on the foundations and foundations of the reconstructed buildings and structures taken in the project largely depend on the quality and completeness of the survey materials $[14,15]$.

One of the main issues in assessing the soil conditions of the construction site of a building being reconstructed is the choice of the bearing layer of the foundation soil for injection piles, into which it is assumed that their lower ends are buried. As a rule, this layer should be the strongest, less compressible in comparison with other engineering-geological elements (soil layers) within the length of the piles and the compressible thickness of the base of the pile foundations.

Assessment of the loading of the foundation base. The assessment of the loading of the base of the foundations (shallow foundation) is understood as the analysis of the initial data and the results of the calculation, in which the correspondence of the size of the base of the considered foundation to the existing loads (N, M, Q) and the soil conditions of the construction site of the reconstructed building is revealed. When assessing the loading of the base of the foundations, the conditions are checked (Fig. 1): 


$$
\begin{gathered}
p_{\max } \leq 1,2 R_{c s} \\
p_{\min } \geq 0, \\
p \leq R_{y n}
\end{gathered}
$$

where $p$ - average pressure along the foot of the foundation (before and after reconstruction

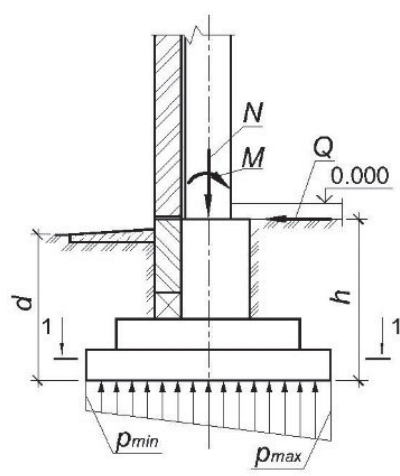

$1-1$

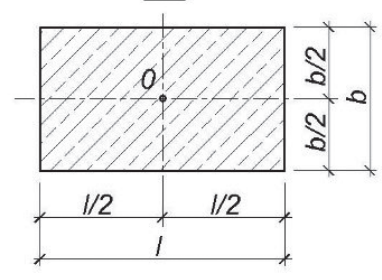

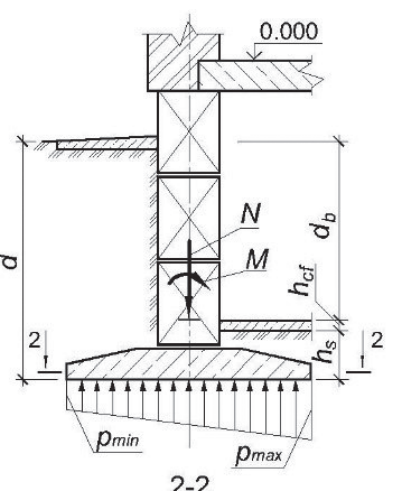

2-2

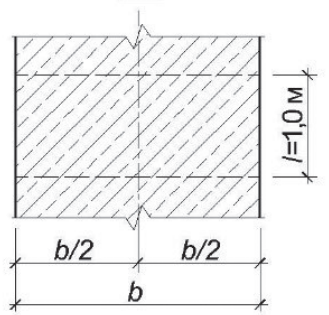

of the building), $\mathrm{kPa} ; R_{c s}$ - design resistance of the compacted soil of the base, $\mathrm{kPa} ; p_{\max }$, $p_{\min }$ - respectively, the maximum and minimum pressure along the foot of the foundation before and after the reconstruction of the building, $\mathrm{kPa}$.

Figure 1. Design diagrams of the projected foundations of reconstructed buildings: $a$ - a free-standing foundation for a building without a basement; $b$-strip foundation for a building with a basement; $p_{\max }, p_{\min }-$ respectively, the maximum and minimum pressure on the base of the foundation, $k P a ; l$, $b$ - respectively, the length and width of the base of the foundation, $m ; d$-foundation depth, $m ; h$ - foundation height, $m ; Q, N, M$-loads acting on the foundation; $h_{s}$ - thickness of the soil layer above the foot of the foundation from the basement side, $m ; h_{c f}$ basement floor structure thickness, $m ; d_{b}^{c f}$-basement depth, $m$

where $K_{\gamma}, K_{c}$ coefficients taking into account changes in density characteristics $\rho$ (specific gravity $\gamma_{\text {II }}$ ) and specific cohesion $c$ of base soils under the foundation during the period of operation of the building; $M_{v}, M_{q}, M_{c}$ - coefficients adopted according to SP 22.13330.2016 depending on the characteristics of the angle of internal friction of the soil $\overline{\varphi_{\text {II }}}$ base, compacted by pressure $p$ from the building in use:

$$
\overline{\varphi_{\mathrm{II}}}=\varphi_{\mathrm{II}} \cdot K_{\varphi}
$$
the foundations of long-term buildings. In general, the design resistance of the compacted soil of the base Rcs is determined by the formula [16]:

$$
\begin{aligned}
R_{\mathrm{y \Pi}}=\frac{\gamma_{c 1} \cdot \gamma_{c 2}}{K} \cdot\left(M_{\gamma} \cdot K_{z} \cdot b \cdot \gamma_{\mathrm{II}} \cdot K_{\gamma}\right. \\
+M_{q} \cdot d_{1} \cdot \gamma_{\mathrm{II}}^{\prime} \\
\quad+\left(M_{q}-1\right) \cdot d_{b} \cdot \gamma_{\mathrm{II}}^{\prime}+ \\
\left.+M_{c} \cdot c_{\mathrm{II}} \cdot K_{c}\right) \cdot K_{s}
\end{aligned}
$$

$\varphi_{\mathrm{II}}$ - angle of internal friction of natural (noncompacted) foundation soil, degrees; $K_{\varphi}-$ coefficient taking into account the change in the characteristic of the angle of internal friction for the period of building operation; $K_{s}$ - coefficient taking into account the degree of implementation (use) of the maximum foundation settlement 
during the period of the building's operation. The rest of the notation is the same as in formula (5.7) SP 22.13330.2016.

Coefficient values $K_{\gamma}, K_{\varphi}, K_{c}$ established experimentally for clayey soils. They are selected depending on the ratio of the average pressure $p$ along the base of the operating foundation to the design resistance of the natural (uncompacted) soil of the foundation $\mathrm{R}$, which was taken during the initial design of the object (p/R). Values of coefficients $K_{\vartheta}, K_{\varphi}, K_{c}$ accepted by [13, table 16.3 ; 16, table 6.1].

The value of the coefficient $K_{s}$ varies from 1 to 1.4 , depending on how fully the ultimate foundation settlement $s$ for the building under consideration is realized during its operation. The largest value of the $K_{s}$ coefficient is taken when the calculated (actual) settlement of the foundation s of the existing building, established at the actual pressure $\mathrm{p}$, is less than $20 \%$ of the maximum permissible $s_{u}\left(s<0.2 s_{u}\right)$. If the calculated (actual) foundation settlement $s$ is more than $70 \%$ of the maximum permissible su $\left(s>0.7 s_{u}\right)$, then the value of the $K_{s}$ coefficient is taken to be one $\left(K_{s}=1\right)$. The values of the coefficients $K_{s}$ are taken according to [13, table. 16.4 ; 16 , table 6.2 ].

In the event that one or two of the conditions (1) are not met, then a decision is made on the need to strengthen the foundation (strengthening the base) of the reconstructed building.

Method for setting up injection piles. After assessing the loading of the base of the foundation (shallow foundation) and making a decision on the need to strengthen it, one of the two main methods
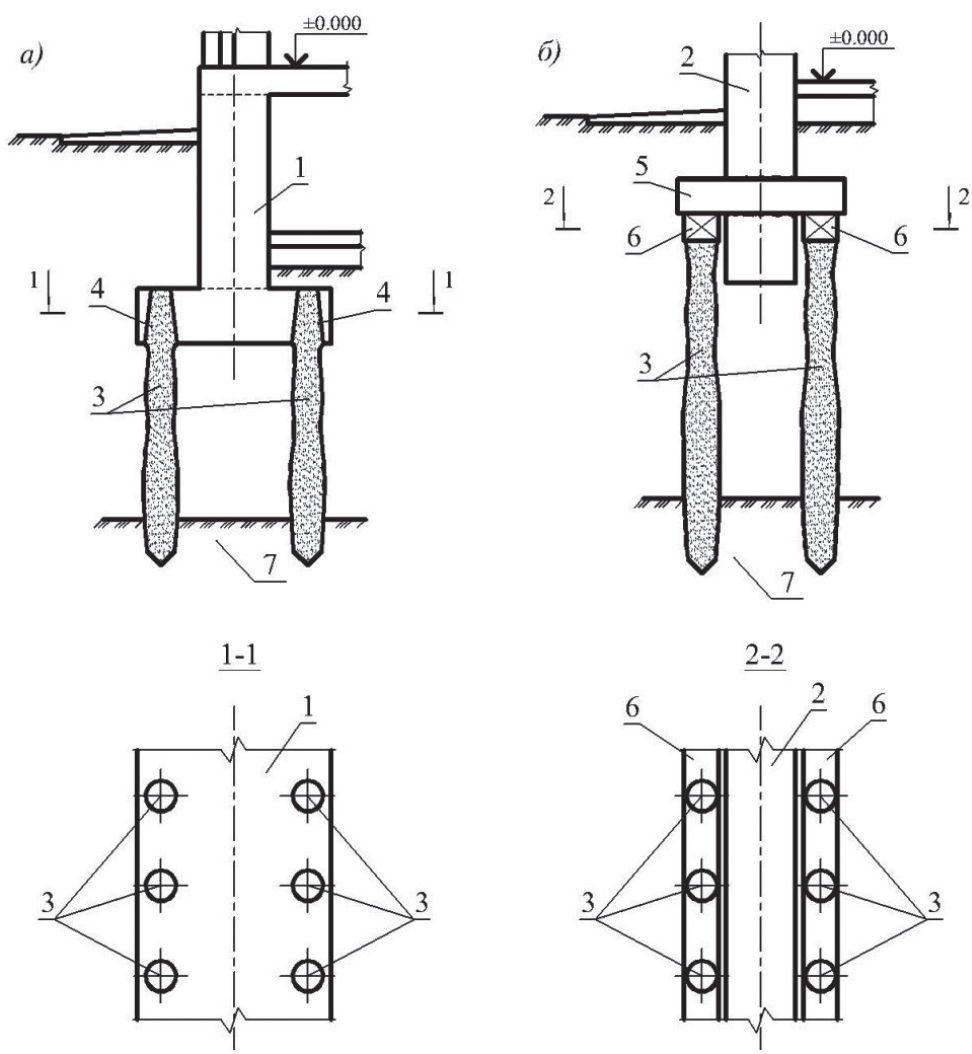

Figure 2. Methods for arranging injection piles when reinforcing strip foundations of reconstructed buildings: $a, b$-respectively, under the sole of the existing strip foundation and adjacent to its perimeter; 1 - existing strip monolithic reinforced concrete foundation; 2 - existing strip rubble (brick) foundation; 3 -injection pile; 4 - a tapered hole in the slab part of the existing foundation; 5 -transverse metal beam, arranged through a hole in the wall part of the existing strip foundation; 6 - longitudinal reinforced concrete beam; 7 - bearing layer of solid (low-compressive) soil 

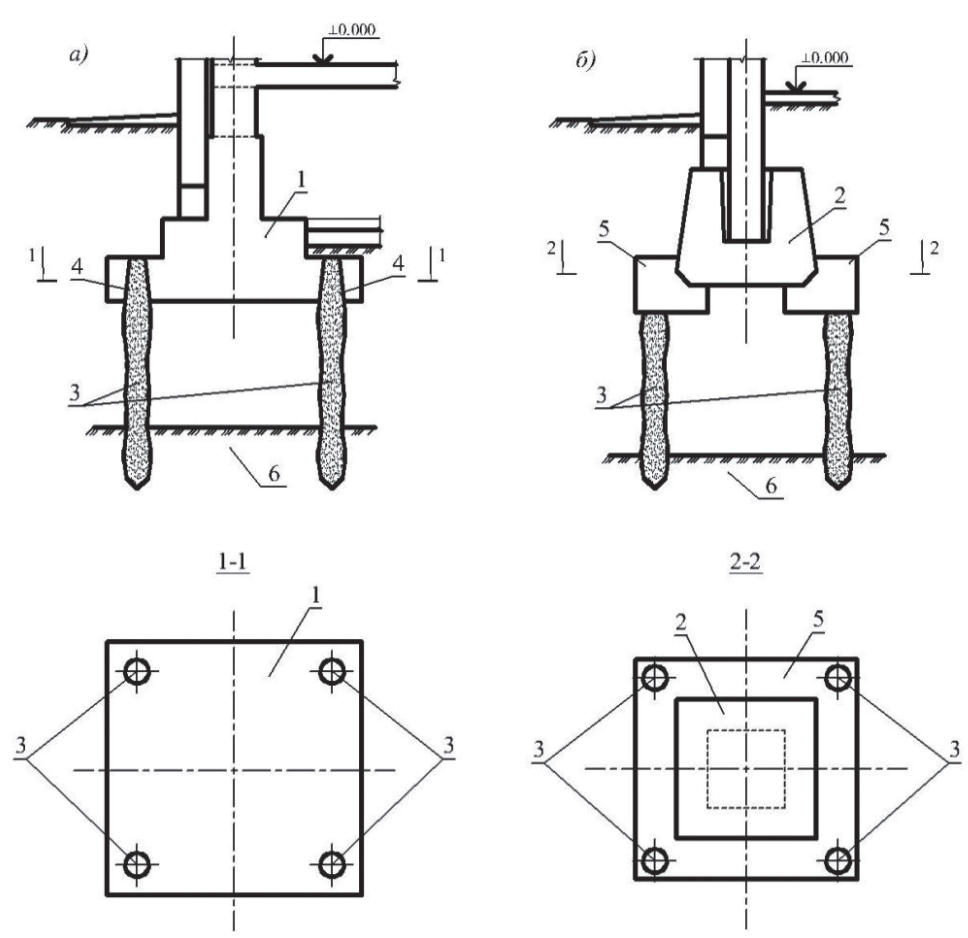

Figure 3. Methods for installing injection piles when strengthening individual foundations of reconstructed buildings: $a, b$-respectively, under the sole of the existing separate foundation and adjacent to its perimeter; 1 - existing separate monolithic reinforced concrete foundation;

2 - existing separate precast reinforced concrete foundation; 3 -injection pile; 4 - a tapered hole in the slab part of the existing foundation; 5 - reinforced concrete cage, arranged along the perimeter of the foundation; 6-bearing layer of solid (low-compressive) soil

of installing injection piles and transferring to them and below the soils of the base part of the load from overhead building structures is selected. Such piles can be installed directly under the base of the existing foundation (first method) or adjacent along its perimeter (second method) (Fig. 2, 3). The foundation arranged in this way is often called combined. In this case, the combined foundation can be single-pile (if one pile is arranged under a column or pillar), cluster (if two or more piles are arranged) and in the form of a pile field (if ten or more piles are arranged under the existing foundation).

In the first method, injection piles, arranged directly under the base of the foundation, transfer part of the external load to the bearing layer of the solid foundation soil within the contour (perimeter) of the base of the existing foundation (Fig. 2a, 3a).
According to the second method, piles are arranged along the contour or along the perimeter of the sole of the existing foundation (strip and separate). Part of the external load on the supporting solid layer of the foundation soil is transferred to the injection piles adjacent to the foundation. The junction of the piles with the body of the foundation (the base of the foundation) is usually arranged rigid and equal in strength (Fig. 2b, 3b) [16, 17].

Justification of the bearing capacity of piles. Let us consider the assessment of the bearing capacity of injection piles. Their bearing capacity $F_{d}$ is understood as the limiting resistance of the near-pile basement soil to their movement under load. To estimate $F_{d}$, the bearing layer of the foundation soil is selected according to the engineering-geological section, in which the lower ends of the piles are arranged (see above). The choice is made in favor of the most durable soil 
layer, less compressible in comparison with other upstream engineering-geological elements. Weak soils (varieties of clayey soils of fluid-plastic and fluid consistency, loose sands, peat, etc.) are not recommended to be used as a bearing layer of the base of combined foundation.

The value of the bearing capacity of the hanging pile $F_{d}$ can be pre-determined analytically by the physical and mechanical characteristics of the base soil using the formula (7.8) according to SP 24.13330.2011 - Pile foundations:

$$
F_{d}=\gamma_{c} \cdot\left(\gamma_{c R} \cdot R \cdot A+u \cdot \sum_{i=1}^{n} \gamma_{c f} \cdot f_{i} \cdot h_{i}\right)
$$

Considering the data for determining the bearing capacity of injection piles $F_{d}$ according to condition (4), the following should be noted. At the initial stage of performing work on their device, a metal injector is pressed into the ground without its excavation, which is similar to the method of immersing piles by indentation. But the supply of fine-grained mobile concrete under pressure into the well (through the injector) and its further pressure testing have common features of the technological processes of the injection pile device. Therefore, the peculiarities of the injection pile device do not
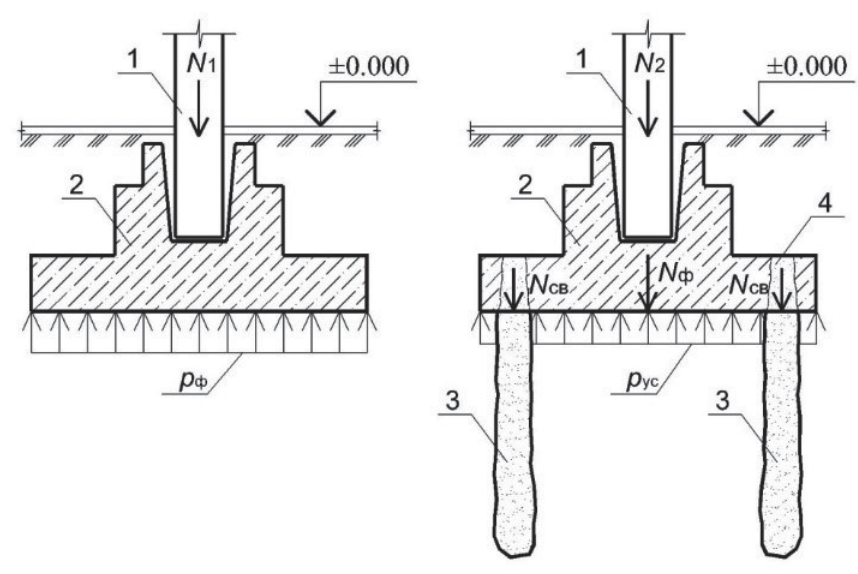

Volume 17, Issue 1, 2021 allow to fully use the values of the coefficients $\gamma_{c R}$ and $\gamma_{c f}$ provided in the regulatory and other technical literature. Thus, formula (4) for injection piles often leads to significant reserves of their bearing capacity, and, often, does not reflect the features of the device technology. Consequently, the values of $F_{d}$ established by the calculation according to (4) should be considered as preliminary, which need additional verification. It should also be noted that the method for determining $F_{d}$ according to (4) is used more often for conditions of new construction and does not take into account the stress-strain state of the soil of the foundation of the building being reconstructed. In recent years, methods for determining the bearing capacity $F_{d}$ of injection piles for foundations of reconstructed buildings have been developed, which are based on the results of experimental and theoretical studies. The results of these studies can be found in the papers $[7,9,10,13]$.

Foundation design. When designing foundations, taking into account their reinforcement, first analyze the data on loads $N_{1}$ and $N_{2}$ at the floor elevations of the first (basement) floor before and after the reconstruction of the building (Fig. 4). The planned number of injection piles required to strengthen the foundation, as well as the choice of the method of transferring additional load $\Delta \mathrm{N}$ from the building $\Delta N=N_{2}-N_{1}$, to them significantly depends on the

\section{Figure 4. Scheme of distribution of external load from the reconstructed building between the elements of the foundation: a-before its strengthening; $b$-after reinforcement with injection piles; 1 -column; 2 - separate foundation; 3 -injection pile; $N_{1}$ is the load on the foundation before the reconstruction of the building; $\mathrm{N}_{2}$-load on the foundation after the re-construction of the building; $N_{f}$ is the load transferred to the slab part of a separate foundation under conditions of building reconstruction; $N_{s v}$ - the same, transferred to injection piles; $p_{f}$ - pressure on the sole of a separate foundation before its strengthening; $p_{y c}$ - pressure along the bottom of a separate foundation after its strengthening}


difference between these loads $N_{1}$ and $N_{2}$. Then, the calculation of the proportion of loads transmitted to the base soil by the base of the foundation $N_{f}$ and injection piles $N_{w}$. The share of $N_{f}$ is calculated taking into account the strength (bearing capacity) of the foundation soil and the pressure pf $\left(\operatorname{load} N_{1}\right)$ from the building before its reconstruction $[12,17]$. Next, they begin to design the foundations, taking into account its reinforcement with injection piles (Fig. 4). Assign the geometric dimensions of additional structural elements of the reinforcement (beams, clips, grillages, struts, tides, etc.). In the presence of significant defects in the pocket foundation (for individual shallow foundations) or in the wall, slab parts of the foundation (for strip foundations), their preliminary restoration is envisaged.

Verification calculations of the base of foundations. Verification calculations of the base of foundations, taking into account their reinforcement by injection piles, are performed according to the first and second groups of limiting states (in terms of bearing capacity and deformations). The complexity of such calculations lies in the fact that the base of the existing foundation is in a stressed state, as it experiences pressure from the reconstructed building, which must be taken into account in the design. At present, a limited number of methods for calculating the settlement $[8,18]$ and the bearing capacity $[2,6,10]$ of the base of foundations, taking into account their strengthening, have been developed, which have not yet been included in the regulatory documents of Russia. Therefore, quite often in the design of the foundations of reconstructed buildings, taking into account their strengthening, regulatory and technical literature is used, prepared for the design of foundations in conditions of new construction $[2,3,5,19]$.

Strength calculation of foundation elements and their design. The structural elements of the reinforced foundation and the nodes of their interface are calculated in accordance with the methods given in the normative and technical literature (SP 63.13330.2018; SP 16.13330.2017; SP 14.13330.2018; Reference book of geotechnics, 2016, etc.), taking into account those in force on these elements are actual loads and actions. Such structural elements include reinforced concrete clips, stiffening belts, beams, building elements, as well as metal (steel) struts, struts, shelves, anchors, etc. Taking into account the calculations performed, they are designed [17, 20, 21].

Preparation of working documentation. Design of reinforcement of foundations of reconstructed buildings with injection piles provides for the preparation of working documentation. The documentation includes detailed drawings for the performance of work, specifications for the materials used, a work production project (WPP), etc. The working documentation also indicates measures for unloading the building structures of the aboveground part of the building, as well as safety measures during production work to strengthen the foundations.

\section{CONCLUSION}

It has been established that in the conditions of reconstruction of buildings in clay soils, a method of strengthening (increasing the bearing capacity) of shallow foundations by transferring part of the load from aboveground building structures to additionally arranged injection piles is widely developed. At the same time, their device is performed by pressing a metal injector into the ground, followed by injecting a fine concrete mixture into the well. Fine-grained mobile concrete mixture is supplied to the wells formed in this way under pressure, which performs pressure testing. The experience of the reconstruction of buildings shows that by now the main approaches to the design of reinforcement of shallow foundations known from technical and regulatory literature have been developed. However, for the conditions of reconstruction and restoration of buildings, the issues of justifying the bearing capacity of injection piles used to strengthen, design combined foundations, methods of their verification calculations have not yet received proper development. The solution of these issues will make it possible to properly and adequately organize the work of specialists. 


\section{REFERENCES}

1. Pronozin, YA.A. Raschet vzaimodeystviya buroin"yektsionnykh svay s gruntovym osnovaniyem [Calculation of the interaction of bore-injection piles with a soil foundation] / YA. A. Pronozin, M. A. Samokhvalov // Osnovaniya, fundamenty i mekhanika gruntov. - 2018. - No 2. - P. 14-17.

2. Polishchuk A.I. Osnovaniya i fundamenty, podzemnyye sooruzheniya: uchebnik [Foundations and foundations, underground structures: textbook] / A. I. Polishchuk; 2-nd edition, add. - Moscow: Publishing ASV, 2020. - 498 p.

3. Gotman A.L. Svai i svaynyye fundamenty. Izbrannyye trudy: monografiya [Piles and pile foundations. Selected works: monograph] / A. L.Gotman.-Ufa:IDPOUGNTU,2015.-384p.

4. Ponomarev A.B. Podzemnoye stroitel'stvo: ucheb. Posobiye [Underground construction: textbook]/ A. B. Ponomarev, YU. L. Vinnikov. - Perm: Publishing PNIPU, 2014. - 262 p.

5. Konovalov P.A. Osnovaniya i fundamenty rekonstruiruyemykh zdaniy : monografiya [Foundations and foundations of reconstructed buildings: monograph] / P. A. Konovalov, V. P. Konovalov. -5-thedition, remastered and added. - Moscow: Publishing ASV, 2011. - 384 p.

6. Tarasov A.A. O primenenii rezul'tatov staticheskogo zondirovaniya dlya rascheta nesushchey sposobnosti in"yektsionnykh svay v slabykh glinistykh gruntakh [On the use of static sounding results for calculating the bearing capacity of injection piles in weak clay soils] / A. A. Tarasov // Vestnik grazhdanskikh inzhenerov No 5, 2015. $-\mathrm{SPb}$, SPbGASU. - 2015. - P. 68-71.

7. Tarasov A.A. Razvitiye metodov raschota in"yektsionnykh svay $\mathrm{v}$ slabykh glinistykh gruntakh dlya fundamentov rekonstruiruyemykh zdaniy [Development of methods for calculating injection piles in weak clay soils for the foundations of reconstructed buildings]: avtoref. dis. ... cand. tech. sc. Tomsk, 2015. $-23 \mathrm{p}$.
8. Polishchuk A.I. Inzhenernyy metod rascheta osadki in"yektsionnoy svai v glinistom grunte [Engineering method for calculating the settlement of injection piles in clay soil] / A. I. Polishchuk, I. V. Semonov // Osnovaniya, fundamenty i mekhanika gruntov. - 2019. - No 5. - P. 23-28.

9. Polishchuk A.I. Raschet nesushchey sposobnosti buroin"yektsionnykh konicheskikh svay $\mathrm{v}$ glinistykh gruntakh [Calculation of the bearing capacity of bore-injection conical piles in clayey soils] / A. I. Polishchuk, D. A. Chernyavskiy // Osnovaniya, fundamenty i mekhanika gruntov. - 2020. - No 4. - P. 2-7.

10. Petukhov A.A. Sovershenstvovaniye sposoba ustroystva in"yektsionnykh svay v slabykh glinistykh gruntakh dlya usloviy rekonstruktsii zdaniy [Improvement of the method for the construction of injection piles in weak clay soils for conditions of reconstruction of buildings]: dis. ... cand. tech. sc. - Tomsk, 2006. - 192 p.

11. Patent of Russian Federation No 2238366. MPK E 02 D 5/34. Sposob ustroystva in"yektsionnoy svai [The method of the injection pile device] / Polishchuk A. I., Gerasimov O. V., Petukhov A. A., Andriyenko YU. B., Nuykin S. S. ; applicant and patentee of Georeconstruction Research and Production Association CJSC - No. 2003106150/03; declared 03/04/2003; publ. 20.10.2004, Bul. No. 29. - 10 p

12. Polishchuk A.I. Pereraspredeleniye vneshney nagruzki ot otdel'nogo fundamenta zdaniya mezhdu podoshvoy i in"yektsionnymi svayami, ispol'zuyemymi dlya yego usileniya / A. I. Polishchuk, I. V. Semonov // Nauchnoye obespecheniye agropromyshlennogo kompleksa [Redistribution of external load from a separate foundation of the building between the sole and injection piles used to strengthen it]: Proceedings of IX All-Russian conf. of young scientists dedicated to 75-year V. M. Shevtsov / edited by A. G. Koshchayev. - Krasnodar : KubGAU, 2016. - P. 861-862.

13. Spravochnik geotekhnika: osnovaniya, fundamenty i podzemnyye sooruzheniya [Handbook of geotechnics: foundations, foundations and underground structures] / Edited 
by V.A. Il'ichev, R.A. Mangushev.-2-nd edition, added and remastered//Chapter 16. Strengthening the foundations and foundations of buildings and structures (AI Polishchuk, AA Tarasov). M.: Publishing house ASV, 2016. P. 807-850

14. Polishchuk A.I. Analiz gruntovykh usloviy stroitel'stva pri proyektirovanii fundamentov zdaniy : nauch.-prakt. Posobiye [Analysis of soil conditions of construction in the design of building foundations] / A.I. Polishchuk. Moscow : Publishing ASV, 2016. - 104 p.

15. Zakharov M.S. Inzhenerno-geologicheskiye $\mathrm{i}$ inzhenerno-geotekhnicheskiye izyskaniya $\mathrm{v}$ stroitel'stve : ucheb. Posobiye [Engineeringgeological and engineering-geotechnical surveys inconstruction]/M.S.Zakharov,R.A.Mangushev; edited by R. A. Mangushev. - Moscow, SaintPeterburg : Publishing ASV, 2014. - 176 p.

16. Polishchuk A.I. Osnovy proyektirovaniya i ustroystva fundamentov rekonstruiruyemykh zdaniy [Fundamentals of design and construction of foundations of reconstructed buildings] / A.I. Polishchuk. - 3-rd edition, adopted. Nortempton STT : Tomsk : STT, 2007.-476 p.

17. Filippovich A.A. Vzaimodeystviye lentochnykh fundamentov rekonstruiruyemykh zdaniy s glinistym gruntom osnovaniya pri ikh usilenii in"yektsionnymi svayami. Avto-referat [Interaction of strip foundations of reconstructed buildings with clay base soil when reinforced with injection piles] / A. A. Filippovich. Volgograd: VolgGASU, 2014. - 23 p.

18. Polishchuk A.I. Podkhod k raschetu osadki odinochnoy in"yektsionnoy svai v glinistykh gruntakh [Approach to the calculation of the settlement of a single injection pile in clayey soils] / A.I. Polishchuk, I.V. Semonov // Proceedings of International scientific and Technical Conference "Mechanics of soils in geotechnics and foundation engineering." Novocherkassk: LLC"Lik",2018.-P. 227-229.

19. Svai i svaynyye fundamenty. Konstruktsii, proyektirovaniye i tekhnologii : nauch.prakt. posobiye [Piles and pile foundations. Constructions, design and technology] / R. A. Mangushev, A. L. Gotman, V. V. Znamenskiy,
A. B. Ponomarev; edited R. A. Mangusheva. - Moscow: Publishing ASV, 2015. - 320 p.

20. Al'bom konstruktivnykh resheniy po seysmousileniyu kamennykh zdaniy i sooruzheniy[Album of constructivesolutions forseismic reinforcement of stone buildings and structures] / G. P. Tonkikh, A. S. Morozov, K. A. Demidov and etc.; under editorship of G. P. Tonkikh, O. V. Kabantsev. - Tomsk; Moscow: Publishing «Pechatnaya manufaktura», 2010. - 114 p.

21. Plevkov V.S., Mal'ganov A.I., Baldin I.V. Otsenka tekhnicheskogo sostoyaniya, vosstanovleniye i usileniye stroitel'nykh konstruktsiy inzhenernykh sooruzheniy: uchebnoye posobiye [Assessment of the technical condition, restoration and strengthening of building structures of engineering structures] / Edited by V.S. Plevkov. 2-nd edition, remastered and added. - Moscow: Publishing ASV, 2014. - 328 p.

\section{СПИСОК ЛИТЕРАТУРЫ}

1. Пронозин, Я.А. Расчет взаимодействия буроинъекционных свай с грунтовым основанием / Я. А. Пронозин, М. А. Самохвалов // Основания, фундаменты и механика грунтов. - 2018. - № 2. - С. 14-17.

2. Полищук А.И. Основания и фундаменты, подземные сооружения: учебник / А. И. Полищук; 2-е изд., доп. - М.: Изд-во ACB, 2020. -498 c.

3. Готман А.Л. Сваи и свайные фундаменты. Избранные труды : монография / А. Л. Готман. - Уфа : ИДПО УГНТУ, 2015. - 384 с.

4. Пономарев А.Б. Подземное строительство : учеб. пособие / А. Б. Пономарев, Ю. Л. Винников. -Пермь: Изд-во ПНИПУ, 2014.-262 с.

5. Коновалов П.А. Основания и фундаменты реконструируемых зданий : монография / П. А. Коновалов, В. П. Коновалов. - 5-е изд. перераб. и доп. - М. : Изд-во АСВ, 2011. - 384 с.

6. Тарасов А.А. О применении результатов статического зондирования для расчета несущей способности инъекционных свай в 
слабых глинистых грунтах / А. А. Тарасов // Вестник гражданских инженеров № 5, 2015 г. - СПб, СПбГАСУ. - 2015. - С. 68-71.

7. Тарасов А.А. Развитие методов расчёта инъекционных свай в слабых глинистых грунтах для фундаментов реконструируемых зданий: автореф. дис. ... канд. техн. наук. - Томск, 2015. - 23 с.

8. Полищук А.И. Инженерный метод расчета осадки инъекционной сваи в глинистом грунте / А. И. Полищук, И. В. Семёнов // Основания, фундаменты и механика грунтов. - 2019. - №5. - С. 23-28.

9. Полищук А.И. Расчет несущей способности буроинъекционных конических свай в глинистых грунтах / А.И. Полищук, Д.А. Чернявский // Основания, фундаменты и механика грунтов. - 2020. - №4. - С. 2-7.

10. Петухов А.А. Совершенствование способа устройства инъекционных свай в слабых глинистых грунтах для условий реконструкции зданий: дис. ... канд. техн. наук. - Томск, 2006. - 192 с.

11. Пат. 2238366. Российская Федерация, МПКЕ 02 D 5/34. Способ устройства инъекционной сваи/ПолищукА.И., Герасимов О.В., Петухов А.А., Андриенко Ю.Б., Нуйкин С.С. ; заявитель и патентообладатель $3 \mathrm{AO}$ «Научно-производственное объединение "Геореконструкция"» -№ 2003106150/03; заявл. 04.03.2003; опубл. 20.10.2004, Бюл. № 29. - 10 с.

12. Полищук, А. И. Перераспределение внешней нагрузки от отдельного фундамента здания между подошвой и инъекционными сваями, используемыми для его усиления / А. И. Полищук, И. В. Семёнов // Научное обеспечение агропромышленного комплекса : сб. ст. по материалам IX Всерос. конф. молодых ученых, посвящ. 75-летию В. М. Шевцова / отв. за вып. А. Г. Кощаев. - Краснодар : КубГАУ, 2016. - С. 861-862.

13. Справочник геотехника: основания, фундаменты и подземные сооружения / Под общ. ред. В. А. Ильичева и Р. А. Мангушева. - 2-е изд., доп. и перераб. // Глава 16. Усиление оснований и фундаментов зданий и сооружений (А. И. Полищук, А. А. Тарасов). - М. : Изд-во АСВ, 2016. С. 807-850.

14. Полищук А.И. Анализ грунтовых условий строительства при проектировании фундаментов зданий : науч.-практ. пособие / А. И. Полищук. - М. : Изд-во АСВ, 2016. - 104 с.

15. Захаров М.С. Инженерно-геологические и инженерно-геотехнические изыскания в строительстве : учеб. пособие / М. С. Захаров, Р. А. Мангушев; под ред. Р. А. Мангушева. - М., СПб. : Изд-во АСВ, 2014. - $176 \mathrm{c}$.

16. Полищук А.И. Основы проектирования и устройства фундаментов реконструируемых зданий / А. И. Полищук. -3-е изд., доп. Нортэмптон STT : Томск : STT, 2007. -476 c.

17. Филиппович А.А. Взаимодействие ленточных фундаментов реконструируемых зданий с глинистым грунтом основания при их усилении инъекционными сваями. Автореферат / А. А. Филиппович. - Волгоград: ВолгГАСУ, 2014. - 23 с.

18. Полищук А.И. Подход к расчету осадки одиночной инъекционной сваи в глинистых грунтах / А. И. Полищук, И. В. Семёнов // Материалы международной научно-технической конференции «Механика грунтов в геотехнике и фундаментостроении». - Новочеркасск: ООО «Лик», 2018. - С. 227-229.

19. Сваи и свайные фундаменты. Конструкции, проектирование и технологии : науч.-практ. пособие / Р. А. Мангушев, А. Л. Готман, В. В. Знаменский, А. Б. Пономарев; под ред. Р. А. Мангушева. - М. : Изд-во АСВ, 2015.-320 с.

20. Альбом конструктивных решений по сейсмоусилению каменных зданий и сооружений / Г. П. Тонких, А. С. Морозов, К. А. Демидов и др.; под общ. ред. Г. П. Тонких, О. В. Кабанцева. - Томск; М.: Изд-во «Печатная мануфактура», 2010. - 114 с.

21. Плевков В.С., Мальганов А.И., Балдин И.В. Оценка технического состояния, восстановление и усиление строительных конструкций инженерных сооружений: учебное пособие / Под ред. В. С. Плевкова. 2-е изд. перераб. и доп. - М.: Изд-во АСВ, 2014. -328 с. 
Polishchuk Anatoly Ivanovich, Head of the Department "Foundations and Foundations" of the Kuban State Agrarian University named after I.T. Trubilina (Krasnodar), Honored Builder of the Russian Federation, Honorary Worker of Higher Professional Education of the Russian Federation, holder of an honorary diploma of the President of the Russian Federation, doct. tech. sciences, professor. Specialist in the field of foundation construction, survey and reconstruction of buildings. Member of the Presidium of the Russian Society for Soil Mechanics, Geotechnical Engineering and Foundation Engineering, holder of the N.M. Gersevanov medal. Author, co-author of 6 monographs, 2 regional normative documents, 18 educational and scientific-practical manuals, 2 reference books, 36 patents for inventions and utility models; more than 260 scientific publications in total. (Russia, 350044, Krasnodar, Kalinina St., 13. Tel. +7 (918) 293-97-30, Em: ofpai@mail.ru).

Nadezda Sergeevna Nikitina, PhD, Department of "Soil Mechanics and Geotechnical", Moscow State University of Civil Engineering (National Research University), 26, Yaro-slavskoe Shosse, Moscow, 129337, Russia; phone/ fax:+7(495) 287-49-14; e-mail: nsnikitina@mail.ru.

Petukhov Arkady Alexandrovich. Director of the LLC "Stroyinvestinnovatsiya TDSK" (Tomsk), associate professor of the department "Foundations and foundations" of the Kuban State Agrarian University named after I. T. Trubilina (Krasnodar), Cand. tech. sciences, associate professor. Specialist in the field of engineering and geological surveys, reconstruction of buildings and geotechnical construction. Author, co-author of more than 80 scientific papers, 15 patents for inventions and utility models.

Semyonov Ivan Vladimirovich. Senior lecturer, post-graduate student of the Department of Foundations and Foundations of the Kuban State Agrarian University named after I. T. Trubilina. Scientific and practical interests: improvement of constructive solutions for injection, bore-injection piles and methods of their calculation, computer support for scientific and design work in construction. Author, coauthor of 4 scientific and practical and teaching aids, 18 scientific articles and 4 patents of the Russian Federation for inventions.

Полищук Анатолий Иванович, Заведующий кафедрой «Основания и фундаменты» Кубанского государственного аграрного университета им. И. Т. Трубилина (г. Краснодар), заслуженный строитель РФ, почетный работник высшего профессионального образования РФ, обладатель почетной грамоты Президента РФ, докт. техн. наук, профессор. Специалист в области фундаментостроения, обследования и реконструкции зданий. Член Президиума Российского общества по механике грунтов, геотехнике и фундаментостроению, обладатель медали Н.М.Герсеванова. Автор, соавтор 6 монографий, 2 региональных нормативных документов, 18 учебных и научно-практических пособий, 2 справочников, 36 патентов на изобретения и полезные модели; всего более 260 научных печатных работ. (Россия, 350044, г. Краснодар, ул. Калинина, 13. Тел. 7 (918) 293-97-30, Em: ofpai@mail.ru).

Никитина Надежда Сергеевна. Директор издательства Ассоциации строительных ВУЗов (Москва), профессор кафедры механики грунтов и геотехники Национального исследовательского Московского государственного строительного университета (НИУ МГСУ), канд. техн. наук, профессор. Научно-практические интересы: механика грунтов, фундаментостроение, промышленное, гражданское и геотехническое строительство. Почетный работник высшего профессионального образования РФ, автор более 50 научных работ. (Россия, 129337, Москва, Ярославское шоссе, д. 26, Высотное здание, оф. 511. Тел. +7 (926) 010-91-55; Em: nsnikitina@mail.ru).

Петухов Аркадий Александрович. Директор предприятия ООО «Стройинвестинновация ТДСК» (г. Томск), доцент кафедры «Основания и фундаменты» Кубанского государственного аграрного университета им. И. Т. Трубилина (г. Краснодар), канд. техн. наук, доцент. Специалист в области инженерно-геологических изысканий, реконструкции зданий и геотехнического строительства. Автор, соавтор более 80 научных работ, 15 патентов на изобретения и полезные модели.

Семёнов Иван Владимирович. Старший преподаватель, аспирант кафедры «Основания и фундаменты» Кубанского государственного аграрного университета им. И. Т. Трубилина. Научно-практические интересы: совершенствование конструктивных решений инъекционных, буроинъекционных свай и методов их расчета, компьютерное обеспечение научных и проектных работ в строительстве. Автор, соавтор 4 научно-практических и учебно-методических пособий, 18 научных статей и 4 патентов РФ на изобретения. 